\title{
Equine coital exanthema caused by equid alphaherpesvirus 3: a report of an outbreak in northeastern Brazil ${ }^{1}$
}

\author{
Givaldo B. Silva Filho ${ }^{(\mathbb{D})}$, Hisadora A.S.C Bom² (D), Silvio M.C. Fonseca² (D), \\ Érica A. $\operatorname{Costa}^{3}$ (D), Beatriz S.A.S. Santos ${ }^{3}$ (D), Renato L. Santos ${ }^{4}$ (D), \\ Francisco A.L. Souza ${ }^{2}$ (D) Joaquim Evêncio Neto ${ }^{2}$ (D) \\ and Fábio S. Mendonça ${ }^{2 *}$ (i)
}

\begin{abstract}
Silva Filho G.B., Bom H.A.S.C., Fonseca S.M.C., Costa E.A., Santos B.S.A.S., Santos R.L., Souza F.A.L., Evêncio Neto J. \& Mendonça F.S. 2021. Equine coital exanthema caused by equid alphaherpesvirus type 3: a report of an outbreak in northeastern Brazil. Pesquisa Veterinária Brasileira 41:e06877, 2021. Laboratório de Diagnóstico Animal, Universidade Federal Rural de Pernambuco, Rua Dom Manoel de Medeiros, s/n, Dois Irmãos, Recife, PE 52171-900, Brazil.E-mail: fabio.mendonca@ufrpe.br

Equine coital exanthema is a venereal infectious disease poorly reported in horses in Brazil and was never described in the northeastern region of the country. This work aims to describe the clinical and pathological aspects of an outbreak of equine coital exanthema caused by equid alphaherpesvirus 3, occurred in a herd of horses at the semiarid region of the State of Rio Grande do Norte. Main clinical signs consisted of anorexia, hiporexia, fibrinous or purulent secretion in the penis mucosa and vagina. Two mares presented mild to minimal lesions that consisted of scars in the mucosa of the vagina and in the perivulvar region. In a stallion the disease consisted of severe, multifocal, umbilicated-exanthematous ulcers of approximately $1 \mathrm{~cm}$ in diameter on the penis mucosa. Other areas where ulcers and crusts were focally observed included the skin of the scrotum and on the lips and mucocutaneous junctions of the oral cavity. Histologically, the main lesion consisted of multifocal severe ulcerative and fibrinous necrotizing balanoposthitis and mild multifocal necrotizing, lymphocytic dermatitis in the lips and scrotum. The equide alphaherpesvirus 3 DNA was amplified in blood samples and penis mucosa using the PCR technique. This is the first report of molecular diagnosis of equine coital exanthema affecting horses in northeastern Brazil. Further studies should be carried out in order to investigate the epidemiology and the importance of this herpetic disease in the country.
\end{abstract}

INDEX TERMS: Equine coital exanthema, equid alphaherpesvirus 3, Brazil, horses, balanopostitis, vaginitis.

\begin{abstract}
RESUMO.- [Exantema coital equino causado pelo alphaherpesvirus equídeo tipo 3: relato de um surto no nordeste do Brasil.] 0 exantema coital equino é uma doença infecciosa venérea pouco relatada em equinos no Brasil e nunca
\end{abstract}

\footnotetext{
${ }^{1}$ Received on March 23, 2021.

Accepted for publication on April 7, 2021.

${ }^{2}$ Laboratório de Diagnóstico Animal, Departamento de Morfologia e Fisiologia Animal, Universidade Federal Rural de Pernambuco (UFRPE), Rua Dom Manoel s/n, Dois Irmãos, Recife, PE 52171-900, Brazil. *Corresponding author: fabio.mendonca@ufrpe.br

${ }^{3}$ Laboratório de Pesquisa em Virologia Animal II, Departamento de Medicina Veterinária Preventiva, Escola de Veterinária, Universidade Federal de Minas Gerais (UFMG), Campus Pampulha, Av. Antônio Carlos 6627, Belo Horizonte, MG 31270-901, Brazil.

${ }^{4}$ Laboratório de Patologia Molecular, Departamento de Clínica e Cirurgia Veterinárias, Escola de Veterinária, Universidade Federal de Minas Gerais (UFMG), Campus Pampulha, Av. Antônio Carlos, 6627, Belo Horizonte, MG 31270-901, Brazil.
}

descrita na região Nordeste do país. Este trabalho tem como objetivo descrever os aspectos clínicos e patológicos de um surto de exantema coital equino causado pelo alphaherpesvirus equídeo 3 , que ocorreu em um haras na região semiárida do Estado do Rio Grande do Norte. Os principais sinais clínicos consistiram em anorexia, hiporexia, secreção fibrinosa ou purulenta na mucosa do pênis e vagina. Duas éguas apresentavam lesões discretas que consistiam em cicatrizes na mucosa da vagina e na região perivulvar. Em um garanhão, a doença consistia em úlceras umbilicadas-exantematosas severas, multifocais, de aproximadamente $1 \mathrm{~cm}$ de diâmetro na mucosa do pênis. Outras áreas onde úlceras e crostas foram observadas focalmente incluíram a pele do escroto, lábios e junções mucocutâneas da cavidade oral. Histologicamente, as principais lesões consistiam em balanopostite multifocal ulcerativa e necrosante fibrinosa grave e dermatite linfocítica necrosante multifocal leve nos 
lábios e escroto. O DNA do alphaherpesvirus equídeo tipo 3 foi amplificado em amostras de sangue e mucosa do pênis pela técnica de PCR. Este é o primeiro relato de diagnóstico molecular de exantema coital equino afetando cavalos no nordeste do Brasil. Novos estudos devem ser realizados a fim de investigar a epidemiologia e a importância dessa doença herpética no país.

TERMOS DE INDEXAÇÃO: Exantema coital equino, alphaherpesvirus equideo-3, Brasil, equinos, balanopostite, vaginite.

\section{INTRODUCTION}

Equid alphaherpesvirus 3 (EHV-3), the etiologic agent of equine coital exanthema (ECE), is a virus belonging to the order Herpesvirales, family Herpesviridae, subfamily Alphaherpesvirinae and genus Varicellovirus (ICTV 2021) that is genetically and pathogenically distinct from the other equid herpesviruses (Barrandeguy \& Thiry 2012).

Another types of herpesvirus are known causing distinct diseases and clinical signs in horses: equid alphaherpesvirus 1 (EHV-1), genus Varicellovirus, causing abortions in mares and also keratoconjunctivitis, encephalomyelitis, and neonatal pneumonia (Léon et al. 2008, Dubale 2017, Estima-Silva et al. 2019, Dunuwille et al. 2020); equid gammaherpesvirus 2 (EHV-2), genus Percavirus, that has been found in horses with keratoconjunctivitis, gastroesophageal ulcers, and chronic throat lesions (Agius \& Studdert 1994, Kershaw et al. 2001, Cicolo et al. 2019, Taulescu et al. 2021); equid alphaherpesvirus 4 (EHV-4), genus Varicellovirus, an important cause of acute and fatal rhinopneumonithis in fowls and occasionally associated with equine abortions (Crabb \& Studdert 1995, Gerst et al. 2003); and equid gammaherpesvirus 5 (EHV-5), genus Percavirus, the cause of a severe and progressive syndrome of pulmonary fibrosis in adult horses (Verryken et al. 2010, Williams et al. 2013, Marenzoni et al. 2015, Gulati et al. 2019). A sixth virus, equid alphaherpesvirus 9 (EHV-9), genus Varicellovirus can cause subclinical encephalitides in horses, but until to date the disease was described just under experimental conditions (Hussey et al. 2021).

The EHV-3 is highly contagious and it's mainly sexually transmitted (Seki et al. 2004), but infections may occur by direct cutaneous contact or by transfer of virus-containing secretions from contaminated objects, artificial insemination or embryo transfer (Barrandeguy et al. 2010a, 2010b, Barrandeguy \& Thiry 2012). Other routes of transmission such as contaminated hands, gloves or ultrasound scanner may also occur (Barrandeguy et al. 2010b).

EHV-3 generally causes an acute and mild venereal disease in stallions and mares (Barrandeguy et al. 2008, Barrandeguy \& Thiry 2012, Gulati et al. 2019). EHV-3 incubation period ranges from five to nine days (Ferreira et al. 2010, Barrandeguy \& Thiry 2012) and like other members of the Alphaherpesvirinae, EHV-3 establishes latency after primary infection (Barrandeguy et al. 2008, Gulati et al. 2019). Under stress or following immunosuppression, reactivation from latency often occurs, leading to viral shedding and horizontal transmission (Barrandeguy et al. 2008, Gulati et al. 2019). Initially genital lesions appear as small, raised, and reddish papules, which often remained unnoticed and progress to vesicles, pustules and ulcers on the glans penis and prepuce of affected stallions and on the vaginal, vestibular mucosa and adjacent perineal skin of affected mares (Gibbs et al. 1972, Seki et al. 2004, Barrandeguy et al. 2010a). Less frequently, lesions may involve the teats, lips, and the upper respiratory mucosa (Ferreira et al. 2010, Barrandeguy et al. 2012, Barba et al. 2015). Additionally, EHV-3 can cause subclinical respiratory infection in yearling horses, and it has been isolated from vesicular lesions on the muzzles of foals in contact with infected mares (MacLachlan \& Dubovi 2011).

ECE is endemic in most horse breeding populations worldwide and has been diagnosed in the North and South Americas (Bouchey et al. 1987, Barrandeguy et al. 2010b, Ferreira et al. 2010, Barba et al. 2015), Asia (Uppal et al. 1989, Seki et al. 2004, Kirisawa et al. 2017, Yurov \& Alekseenkova 2018), Europe (Petzoldt 1970, Gibbs et al. 1972), Africa (Dubale 2017), and Oceania (Pascoe et al. 1972). However, information on seroprevalence is limited and reported rates range from $6 \%$ to $48 \%$ (Hussey et al. 2021). For instance, in Brazil there are no epidemiological surveys available, and there is only one report that described the disease in a stallion from Minas Gerais, southeastern region of the country (Ferreira et al. 2010).

Herein we report an outbreak of ECE in a horse farm in the semiarid region of the State of Rio Grande do Norte, northeastern Brazil. In addition, we discuss the literature on the main epidemiologic, clinical, and diagnostic features of ECE in horses.

\section{MATERIALS AND METHODS}

An outbreak of reproductive disease was observed in a herd of 43 horses in an 800-hectares farm in the Seridó Oriental region, Rio Grande do Norte State, northeastern Brazil. The weather in this region is semiarid, with high average temperatures, and scarce and irregularly distributed rain throughout the year. The characteristic biome of this region is the Brazilian Caatinga, which is composed predominantly of xerophytic, woody, thorny, and deciduous vegetation.

The herd consisted of 5 stallions, 17 mares, 8 colts, 5 fillies, and 8 foals. The herd was kept during the day on shaded paddocks, and were separated according to the ages and categories. During the early morning and the late afternoon, the animals were housed in stables, where they received alfalfa hay (Medicago sativa), commercial feed containing corn, barley, oat and bead flakes, and extruded corn and soybean, wheat semen and sugar cane mass. Additionally, horses received mineral salt containing bicalcium phosphate, sodium chloride, magnesium oxide, sodium selenite, calcium iodate, cobalt sulfate, iron sulfate, copper sulfate, and zinc sulfate. Water was available ad libitum 24 hours a day. The horses were routinely vaccinated for rabies, tetanus, encephalomyelitis, and influenza. There was no history of vaccination against herpesviruses.

One of the stallions came from the state of São Paulo, and had been introduced in the herd to be the main breeder of the farm two weeks before the observation of clinical signs. Immediately after arriving, it was used to mate with five mares. Upon clinical examination at 20 days after being introduced in the herd, this stallion was presenting severe clinical signs. Another owner's complaining was that other two mares presenting a constant history of abortions in late pregnancy and a foal was blind due to a severe keratoconjunctivitis of the left eye. No laboratorial tests were performed to diagnosis the causes of abortions in this mares nor the ophthalmic disease in the foal.

The stallion and three mares were clinically examined in detail considering their general condition, rectal temperature, cardiac and respiratory rates, and a thorough examination of the prepuce, 
penis, vagina, perivaginal, and perineal skin. Biopsies of the prepuce and lips of the stallion with severe equine coital exanthema (ECE) signs were collected at the time of examination. The owner did not authorize biopsies in the mares because they had healed lesions. Blood samples were collected by jugular venipuncture using vacuum tubes with ethylenediamine tetraacetic acid (EDTA). Biopsies fragments of the stallion and samples of whole blood of the mares and the stallion were collected for a complete blood count, DNA extraction and polymerase chain reaction (PCR) for EHV-3. DNA extraction from whole blood and tissue was performed using the PureLink $^{\mathrm{TM}}$ Genomic DNA Mini Kit (Invitrogen) according to the manufacturer's recommendations. PCR for detection of EHV-3 genomic DNA was performed with primer sets targeting the viral gene encoding the glycoprotein $\mathrm{G}(\mathrm{gG})$, as described by Dynon et al. (2001). Locations and sequences of primers were as follows: (sense: 792-812) 5'-GCGCTCTCTCGGCCTTGCCAG-3' and (antisense: 13091290) 5'-GGCGTCTCGAAAAGCGAGAG-3'. Amplification reactions were performed in $25 \mu \mathrm{L}$ containing Buffer $1 \mathrm{X}, 2 \mathrm{mM} \mathrm{MgCl}_{2}, 200 \mathrm{mM}$ each dNTP (Invitrogen-BRL), $0.4 \mathrm{pM}$ of each primer, $1 \mathrm{U}$ Taq DNA polymerase (Invitrogen-BRL), and 200ng template DNA. Cycling conditions included five minutes at $95^{\circ} \mathrm{C}, 30$ cycles of $94^{\circ} \mathrm{C}$ for one minute, $60^{\circ} \mathrm{C}$ for one minute, and $72^{\circ} \mathrm{C}$ for one minute, followed by a final extension for 7 minutes at $72^{\circ} \mathrm{C}$. PCR products were analyzed by $1.5 \%$ agarose gel electrophoresis with ethidium bromide staining (Ferreira et al. 2010). Mammalian GADPH was amplified as an internal control of the amplification efficiency, as previously described (Shi \& Roy-Burman 2000) and as a positive control, a DNA sample known to be positive was used.

In addition, biopsies samples from the stallion were fixed in $10 \%$ formaldehyde, routinely processed for histology, stained with hematoxylin and eosin (HE), and evaluated under light microscopy.

After clinical diagnosis, the stallion with lesions of ECE and the mares were kept without sexual activity during 60 days. The stallion received $15 \mathrm{mg} / \mathrm{kg} / \mathrm{IV}$ of sulfa trimethoprim for seven days and local treatment with iodine solution until the cicatrization. In addition, an insecticide spray was applied topically for preventing screwworm infection.

\section{RESULTS}

The outbreak occurred between the end of May to early June of 2018 and the morbidity was $9.3 \%$; four adult horses of 43 at risk were affected. The veterinarian responsible for the herd reported that five mares that mated with the stallion presented hiporexia $(3 / 5)$, serous vaginal secretion $(2 / 5)$, and some vesicles in the vaginal mucosa that evolved to small ulcers $(2 / 5)$. Two of three mares examined presented mild lesions that consisted of discoloration of the perivulvar skin (consistent with healed lesions) and mild hyperemia of the vagina mucosa. In the stallion, the disease was first detected when it refused to mate and showed clinical signs of pain upon exposure of the penis. After five days of the observation of these first clinical signs, the stallion presented mild fever, anorexia and disease progressed to the observation of fibrino-purulent exudate draining from the preputial ostium. During physical examination there were severe, multifocal, umbilicated, exanthematous and erosive circular lesions of approximately $1 \mathrm{~cm}$ in diameter on the glans penis and preputial mucosa (Fig.1). These lesions had hyperemic borders with a center covered by fibrinous exudative material (Fig.2), and eventually formed a coalescing pattern in the body of the penis and in the glans. In addition, multifocal areas of erosions and crusts on the skin and on the mucocutaneous junctions of the prepuce and penis were noted. Other areas where ulcers and crusts were multifocally observed included the skin of the scrotum and on the lips and mucocutaneous junctions of the oral cavity (Fig.3). No changes in the cardiac and respiratory pattern or hematological alterations were observed in the mares or stallion.

Histologically, the main lesion consisted of multifocal severe ulcerative and fibrinous necrotizing balanoposthitis and mild multifocal necrotizing, lymphocytic dermatitis of the lips and scrotum. In the epidermis of the prepuce there was moderate to severe acanthosis, and multifocal areas of acantholysis mixed with inflammatory infiltrate that was composed by degranulated neutrophils, lymphocytes and macrophages. In these areas, there was marked ballooning degeneration of the epithelial cells in the basal and spinosum layers of the epidermis (Fig.4 and 5). Additionally, a significant number of epithelial cells containing evident eosinophilic intranuclear inclusions bodies were observed (Fig.6), and eventually pustules containing coccoid bacteria were identified. In the mucosa of the penis there were multifocal areas of necrosis associated with moderate to severe inflammation, also composed by neutrophils, lymphocytes, macrophages, large amounts eosinophils and fibrin. Less frequently, the same pattern of inflammation in the connective tissue and mild to moderate lymphocytic perivasculitis in the vessels of the dermis of prepuce and penis mucosa was also noted. Similar lesions were observed on the lips and scrotum, but in general they were less severe.

A single amplification product of approximately $518 \mathrm{bp}$ compatible with EHV-3 was amplified from DNA samples extracted from the penis mucosa and whole blood sample of the stallion. There was no amplification of the EHV-3 genetic sequence expected from the blood samples of the three mares examined.

The lesions in the mare's vaginas were cicatrized and no clinical signs of ECE were observed during the following 12 months. After 21 days of treatment, the lesions of the stallion were completely healed.

\section{DISCUSSION AND CONCLUSION}

A diagnosis of equine coital exanthema (ECE) was established based on the epidemiology, clinical signs, gross and histologic findings, and amplification of EHV-3 DNA sequences in samples of penis biopsy and whole blood in one stallion with severe multifocal balanoposthitis. Therefore, EHV-3 was presumptively considered the etiological agent responsible for the reproductive disease observed by the veterinarian of the farm in three affected mares that had vulvovaginitis. The horses' history suggested that the introduction of a stallion two weeks before the onset of the disease may have been responsible for spreading the infection in this herd. This hypothesis is feasible because the primary method of virus transmission is venereal, and occurs due to direct skin-to-skin contact with an acutely infected horse (Allen \& Umphenour 2004, Seki et al. 2004, Lu \& Morresey 2007). Furthermore, the stallion may also have spread the virus via a non-coital way of infection; due the oral or genitonasal contact associated with the behavior of sniffing or licking the mare's genitalia, which has been proposed as one of the possibilities of infection 

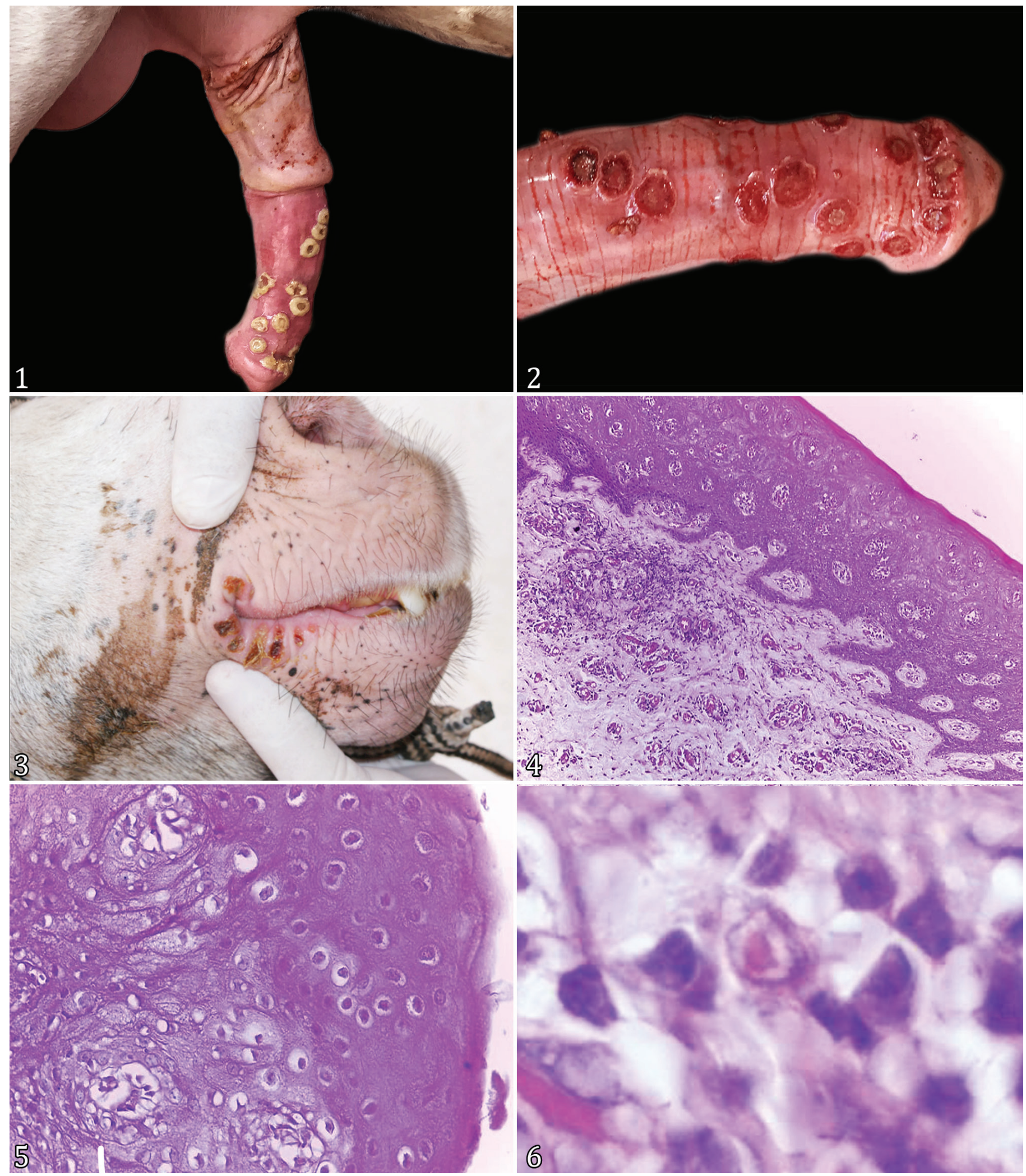

Fig.1-6. Equine coital exanthema in a stallion. (1) Edema, petechial hemorrhages and ulceration of the prepuce, with fibrin-purulent exudation and multifocal umbilicated, exanthematous and erosive circular lesions of approximately $1 \mathrm{~cm}$ in diameter forming a coalescent pattern in the penis mucosa. (2) Closer view of the penis of a stallion with severe ulcerative balanoposthitis with fibrin exsudation. (3) Ulcerative and crusted lesions at the mucocutaneous junction of the mouth in a stallion infected by the herpesvirus type 3. (4) Prepuce with necrotizing dermatitis with acanthosis, a remarkable inflammatory infiltrate and perivasculitis. HE, obj.10x. (5) High magnification of the epidermis of the prepuce with severe ballooning degeneration of keratinocytes and epithelial necrosis. HE, obj.40x. (6) Keratinocyte containing an intranuclear eosinophilic inclusion body measuring 4-7 $\mu \mathrm{m}$. HE, obj.100x. 
and dissemination of the disease (Barrandeguy et al. 2010b, Barrandeguy \& Thiry 2012).

Genital lesions of ECE in horses are quite typical, allowing a presumptive clinical diagnosis (Bryans 1980, Bryans \& Allen 1989, Lu \& Morresey 2007, Barrandeguy \& Thiry 2012), and despite the mares of our study having presented a recent history of vulvovaginitis compatible with ECE, there was no amplification of EHV-3 DNA in their whole blood samples on PCR analysis. The reason for this could be explained by the lack of an ideal temperature for maintenance and multiplication of EHV-3 in the bloodstream, leading to low levels of viremia in some infected horses (Allen \& Umphenour 2004). However, in some cases it is possible to find EHV-3 DNA in blood samples, as we found in the stallion shown here (Ferreira et al. 2010).

To our knowledge, there are no commercial laboratories providing routinely serology tests for EHV-3. Despite this, serum samples are useful for demonstration of seroconversion and antibody titles (Seki et al. 2004, Kirisawa et al. 2017). As it was performed in the case described here, molecular diagnostic techniques are useful for detection of EHV-3 in affected tissues (Bouchey et al 1987, Seki et al. 2004, Vissani et al. 2018, 2020). Therefore, as in this case specimens submitted for laboratory confirmation of EHV-3 may be samples from the edges of fresh, active lesions by biopsy or by firm swabbing or scraping (Ferreira et al. 2010). Blood samples are useful during acute illness until 3-4 weeks later (Ferreira et al. 2010).

Other clinical signs of ECE include tail itching, frequent urination or arching of the back and anorectal lymphadenopathy, constipation, tenesmus, and evacuation of firm, dry, mucuscovered faeces, which have been reported in severely affected mares by EHV-3 (Allen \& Umphenour 2004, Barrandeguy et al. 2010a). These clinical signs were not observed in this study probably because the disease was mild in this group of animals. In contrast, the stallion presented more severe clinical signs of ECE including discomfort, loss of libido and refusal to mount and mate with mares, as previously reported in severe cases (Bryans \& Allen 1989, Allen \& Umphenour 2004, Gulati et al. 2019). Secondary bacterial infection of the genital lesions with Streptococcus zooepidemicus is one important consequence because is common and influences the severity and duration of the epithelial lesions. For this reason, the treatment should include: 1) daily cleaning of the lesions and the genitalia with antiseptics, 2) reducing inflammation with glucocorticoid anti-inflammatory drugs, 3) administration of broad-spectrum antimicrobials and 4) limitation of sexual activities until the lesions have healed to prevent further spread of infection (Allen \& Umphenour 2004, Lu \& Morresey 2007). Additionally, an attempted treatment could be made using a $5 \%$ acyclovir topical cream formulation (Cullinane et al. 1994).

Abortion is not a consequence of EHV-3 infection (Barrandeguy \& Thiry 2012), and until to date there are no studies confirming EHV-3 causing abortions in natural conditions in mares. Abortions can be induced by inoculation of EHV-3 in the amniotic cavity; however, this is an unlikely route of infection (Gleeson et al. 1976). For this reason, concerning the previous clinical history of miscarriage of some mares and keratoconjuntivitis in a foal reported by the farm owner, it is reasonable to hypothesize a possible co-infection of EHV-3 and EHV-1 in this herd. EHV-1 is one of the major causes of viral abortions in mares (Marcolongo-Pereira et al. 2012) and may cause keratoconjunctivitis. Nevertheless, although uncommon, keratitis and periocular lesions can be caused by EHV-3 (Barba et al. 2015). Importantly, no samples from aborted fetuses were sent to our laboratory for diagnosis, and serology for EHV-1 was not performed and other non-viral etiologies could not be ruled out. However, several reports have demonstrated the presence of specific antibodies against EHV-1 in horses in Brazil (Alencar-Araripe et al. 2014, Diaz et al. 2015, Estima-Silva et al. 2019) and further studies to investigate the possible association of different types of equine herpesviruses causing reproductive, respiratory, neurological and ophthalmic disorders, should be made in country.

No vaccines or antiviral therapies are available for ECE. Infected animals just spread EHV-3 when genital or oral lesions are present. Prevention consists of clinical examination of mares and stallions before mating or semen collection and resting them from breeding activities when lesions are present. Furthermore, quarantine must be a regular practice when new animals are introduced in the herd. However, it is important to emphasize that this approach is not sufficient to identify subclinically infected horses or that ones with latent infections, because they show clinical signs that are generally milder than that observed in the first clinical presentation (Barrandeguy et al. 2008, Vissani et al. 2020).

ECE is endemic in most horse breeding populations worldwide and outbreaks can lead to considerable economic loss, because they disrupt breeding activities, cause economic depreciation of mares and stallions, and are costly to deal with (Barrandeguy et al. 2012). Surprisingly, to the best of our knowledge, only one previously reported case of EHV3 infection was definitively associated with the cause of balanoposthitis in a horse in Brazil (Ferreira et al. 2010), and no cases have been reported in mares. Certainly, cases of ECE occurring in all regions of the country have been not diagnosed appropriately or at least are not being reported, and until to date, no wide scientific study was made to measure the economic impact of ECE on the horse business in the country. For these reasons, new studies aiming to evaluate the epidemiology of ECE in Brazil should be made.

Acknowledgements.- To the "Coordenação de Aperfeiçoamento de Pessoal de Nível Superior" (CAPES), Finance Code 001, and "Conselho Nacional de Desenvolvimento Científico e Tecnológico" (CNPq), Process 304804/2018-5, for granting the necessary financial support for the development of this study.

Conflict of interest statement.- The authors declare no conflicts of interest.

\section{REFERENCES}

Agius C.T. \& Studdert M.J. 1994. Equine herpesviruses 2 and 5: comparisons with other members of the subfamily gammaherpesvirinae, p.357-379. In: Ibid. (Eds), Advances in Virus Research. Vol.44. Academic Press, Massachusetts.

Alencar-Araripe MG., Castelo-Branco D., Campelo C.C., Silva A., Silva M.C., Dias A.V., Medeiros C.M.O. \& Nunes-Pinheiro D.C.S. 2014. Serological evidences of EHV-1/EHV-4 in vaquejada horses from Ceará state, Brazil. Revta Bras. Hig. San. Anim. 8(2):203-217. <https://dx.doi.org/10.5935/19812965.20140029>

Allen G. \& Umphenour N. 2004. Equine coital exanthema, p.860-867. In: Coetzer J. \& Tustin R. (Eds), Infectious Diseases of Livestock. Oxford Press, Cape Town.

Barba M., Stewart A.J., Shrader S.M., Koehler J.W., Johnson A.K. \& Caldwell F.J. 2015. Keratitis and periocular lesions associated with equine herpesvirus-3 
in a 3-month-old filly. Equine Vet. Educ. 27(12):618-622.<https://dx.doi. org/10.1111/eve.12365>

Barrandeguy M. \& Thiry E. 2012. Equine coital exanthema and its potential economic implications for the equine industry. Vet. J. 191(1):35-40.<https:// dx.doi.org/10.1016/j.tvjl.2011.01.016><PMid:21354835>

Barrandeguy M., Perkins J., Mac Donough J., Vissani A., Olguin C. \& Thiry E. 2010a. Occurrence of equine coital exanthema in mares from an embryo transfer center. J. Equine Vet. Sci. 30(3):145-149. <https://dx.doi. org/10.1016/j.jevs.2010.01.059>

Barrandeguy M., Ulloa N., Bok K. \& Fernández F. 2010b. Outbreak of rhinitis caused by equine herpesvirus type 3. Vet. Rec. 166(6):178-179. <https:// dx.doi.org/10.1136/vr.c444> <PMid:20139382>

Barrandeguy M., Vissani A., Olguin C., Barbara G., Valenzuela H., Becerra L., Tordoya M., Miño S. \& Thiry E. 2012. Experimental infection with equid herpesvirus 3 in seronegative and seropositive mares. Vet. Microbiol. 160(3/4):319-326. <https://dx.doi.org/10.1016/j.vetmic.2012.06.024> $<$ PMid:22776511>

Barrandeguy M., Vissani A., Olguin C., Becerra L., Miño S., Pereda A., Oriol J. \& Thiry E. 2008. Experimental reactivation of equine herpesvirus-3 following corticosteroid treatment. Equine Vet. J. 40(6):593-595. <https://dx.doi. org/10.2746/042516408x333399><PMid:19031515>

Bouchey D., Evermann J. \& Jacob R.J. 1987. Molecular pathogenesis of equine coital exanthema (ECE): temperature sensitivity (TS) and restriction endonuclease (RE) fragment profiles of several field isolates. Arch. Virol. 92(3/4):293-299. <https://dx.doi.org/10.1007/BF01317485> $<$ PMid:3028334>

Bryans J.T. \& Allen G.P. 1989. Herpesviral diseases of the horse. In: Wittmann G. (Eds), Herpesvirus Diseases of Cattle, Horses, and Pigs: developments in veterinary virology. Vol 9. Springer, Boston.

Bryans J.T. 1980. Herpesviral diseases affecting reproduction in the horse. Vet. Clin. N. Am., Large Anim. Pract. 2(2):303-312. <https://dx.doi.org/10.1016/ s0196-9846(17)30164-7><PMid:6262988>

Cicolo S., Campos A.C.A., Oliveira C.M., Poltronieri T., Góes L.G.B., Silveira V.B., Barbosa C.M., Baccarin R.Y.A., Oliveira D.B.L., Belli C.B. \& Durigon E.L. 2019. Potential outbreak in Brazil by equine herpesvirus type 2 (EHV-2): detection, clinical and genetic analysis of equine gammaherpesvirus 2 . BioRxiv. 809053. <https://dx.doi.org/10.1101/809053>

Crabb B.S. \& Studdert M.J. 1995. Equine herpesviruses 4 (equine rhinopneumonitis virus) and 1 (equine abortion virus), p.153-190. In: Ibid. (Eds), Advances in Virus Research. Vol.45. Academic Press, Massachusetts.

Cullinane A., McGing B. \& Naughton C. 1994. The use of acyclovir in the treatment of coital exanthema and ocular disease caused by equine herpesvirus, p.55. In: Plowright W \& Nakajima H. (Eds), Equine Infectious Diseases. Vol.VII. 3rd ed. R \& W Publications, Newmarket.

Diaz K.A.D., Hübner S.O., Vargas G.D., Fischer G., Lilenbaum W. \& Lima M. 2015. Ocorrência de anticorpos contra o herpesvírus equino e virus da arterite equina em rebanhos equinos do estado do Rio de Janeiro. Ciênc. Anim. Bras. 16(3):410-418. <https://dx.doi.org/10.1590/1089-6891v16i326131>

Dubale H.N. 2017. Epidemiology of equine herpesviruses (EHVs) in Ethiopian equids and invasion characteristics of EHV-1 and EHV-3 in respiratory and genital mucosae. Doctoral Dissertation, Ghent University, Gent, Bélgica. 159p.

Dunuwille W.M.B., YousefiMashouf N., Balasuriya U.B.R., Pusterla N. \& Bailey E. 2020. Genome-wide association study for host genetic factors associated with equine herpesvirus type-1 induced myeloencephalopathy. Equine Vet. J. 52(6):1-5. <https://dx.doi.org/10.1111/evj.13261><PMid:32153055>

Dynon K., Varrasco A., Ficorilli N., Holloway S.A., Reubel G.H., Li F., Hartley C.A., Studdert M.J. \& Baterista H.E. 2001. Identification of equine herpesvirus 3 (equine coital exanthema virus), equine gammaherpesviruses 2 and 5 , equine adenoviruses 1 and 2, equine arteritis virus and equine rhinitis $A$ virus by polymerase chain reaction. Aust.Vet. J. 79(10):695-702.<https:// dx.doi.org/10.1111/j.1751-0813.2001.tb10674.x ><PMid:11712710>
Estima-Silva P., Riet-Correa F., Coelho A.C.B., Echenique J.V.Z., Marcolongo-Pereira C., Lima M., Diel D.G. \& Schild A.L. 2019. Identification of equine herpesvirus type 1 as cause of abortion in mares in Southern Brazil. Arq. Bras. Med. Vet. Zootec. 71(4):1421-1424.<https://dx.doi.org/10.1590/1678-4162-10430>

Ferreira C., Costa E.A., França S.A., De Melo U.P., Drumond B.P., Bomfim M.R.Q., Coelho F.M., Resende M., Palhares M.S. \& Santos R.L. 2010. Equine coital exanthema in a stallion. Arq. Bras. Med. Vet. Zootec. 62(6):1517-1520.

Gerst S., Borchers K., Gower S.M. \& Smith K.C. 2003. Detection of EHV-1 and EHV-4 in placental sections of naturally occurring EHV-1-and EHV-4related abortions in the UK: use of the placenta in diagnosis. Equine Vet. J. 35(5):430-433.<https://dx.doi.org/10.2746/042516403775600451> <PMid:12875318>

Gibbs E.P.J., Roberts M.C. \& Morris J.M. 1972. Equine coital exanthema in the United Kingdom. Equine Vet. J. 4(2):74-80. <https://dx.doi. org/10.1111/j.2042-3306.1972.tb03883.x><PMid:4353678>

Gleeson L.J., Sullivan N.D. \& Studdert M.J. 1976. Equine herpesviruses: type 3 as an abortigenic agent. Aust. Vet. J. 52(8):349-354. <https://dx.doi. org/10.1111/j.1751-0813.1976.tb09485.X><PMid:186003>

Gulati B.R., Virmani N. \& Tripathi B.N. 2019. Equine herpesviruses, p.51-70. In: Malik Y.S., Singh R.K. \& Yadav M.P. (Eds), Recent Advances in Animal Virology. Springer, Singapore.

Hussey G.S., Osterrieder N. \& Azab W. 2021. Equine herpesviruses, p.278286. In: Bamford D.H. \& Zuckerman M. (Eds), Encyclopedia of Virology. Vol.2. 4th ed. Academic Press, Massachusetts.

ICTV 2021. International Committee on Taxonomy of Viruses. Available at <https://talk.ictvonline.org/taxonomy/p/taxonomy-history?taxnode_ id $=201901449>$. Accessed on Mar. 13, 2021.

Kershaw O., von Oppen T., Glitz F., Deegen E., Ludwig H. \& Borchers K. 2001. Detection of equine herpesvirus type 2 (EHV-2) in horses with keratoconjunctivitis. Virus Res. 80(1/2):93-99. <https://dx.doi.org/10.1016/ s0168-1702(01)00299-4> <PMid:11597754>

Kirisawa R., Toishi Y., Akamatsu A., Soejima K., Miyashita T. \& Tsunoda N. 2017. Isolation of equine herpesvirus 3 (EHV-3) from equine coital exanthema of two stallions and sero-epidemiology of EHV-3 infection in Japan. J. Vet. Sci. 79(3):636-643. <https://dx.doi.org/10.1292/jvms.16-0518> <PMid:28132964>

Léon A., Fortier G., Fortier C., Freymuth F., Tapprest J., Leclercq R. \& Pronost S. 2008. Detection of equine herpesviruses in aborted foetuses by consensus PCR. Vet. Microbiol. 126(1/3):20-29. <https://dx.doi.org/10.1016/j. vetmic.2007.06.019><PMid:17686590>

Lu K.G. \& Morresey P.R. 2007. Infectious diseases in breeding stallions. Clin. Tech. Equine Pract. 6(4):285-290. <https://dx.doi.org/10.1053/j. ctep.2007.09.008>

MacLachlan N.J \& Dubovi E.J. 2011. Herpesvirales, p.179-201. In: Ibid. (Eds), Fenner's Veterinary Virology. 4th ed. Academic Press, San Diego.

Marcolongo-Pereira C., Adrien M.D.L., Ladeira S.R., Soares M.P., Assis-Brasil N.D. \& Schild A.L. 2012. Abortos em equinos na região Sul do Rio Grande do Sul: estudo de 72 casos. Pesq. Vet. Bras. 32(1):22-26. <https://dx.doi. org/10.1590/S0100-736X2012000100005>

Marenzoni M.L., Stefanetti V., Danzetta M.L. \& Timoney P.J. 2015. Gammaherpesvirus infections in equids: a review. Vet. Med. Res. Rep. 6:91-101. <https://dx.doi. org/10.2147/VMRR.S39473><PMid:30155436>

Pascoe R.R., Bagust T.J. \& Spradbrow P.B. 1972. Studies on equine herpesviruses: 4 . Infection of horses with a herpesvirus recovered from equine coital exanthema. Aust. Vet. J. 48(3):99-104. <https://dx.doi. org/10.1111/j.1751-0813.1972.tb02225.x>

Petzoldt K. 1970. Equine coital exanthema. Berl. Munch. Tierarztl. 83(5):93-95. <PMid:4314760>

Seki Y., Seimiya Y.M., Yaegashi G., Kumagai S.-I., Sentsui H., Nishimori T. \& Ishihara R. 2004. Occurrence of equine coital exanthema in pastured draft 
horses and isolation of equine herpesvirus 3 from progenital lesions. J. Equine Vet. Sci. 66(12):1503-1508. <https://dx.doi.org/10.1292/ jvms.66.1503><PMid:15644599>

Shi Y. \& Roy-Burman P. 2000. A novel truncated env gene isolated from a feline leukemia virus-induced thymic lymphosarcoma. J.Virol. 74(3):1451-1456. <https://dx.doi.org/10.1128/jvi.74.3.1451-1456.2000><PMid:10627556>

Taulescu M., Amorim I. \& Washabau R. 2021. Esophagus and stomach, p.380393. In: Sharkey L.C., Radin M.J. \& Seelig D. (Eds), Veterinary Cytology. Wiley-Blackwell, Hoboken.

Uppal P.K., Yadav M.P., Singh B.K. \& Prasad S. 1989. Equine coital exanthema (EHV-3 virus) infection in India. J. Vet. Med. 36(1/10):786-788. <https:// dx.doi.org/10.1111/j.1439-0450.1989.tb00674.x><PMid:2559563>

Verryken K., Saey V., Maes S., Borchers K., Van de Walle G., Ducatelle R. \& Deprez P. 2010. First report of multinodular pulmonary fibrosis associated with equine herpesvirus 5 in Belgium. Vlaams Diergen Tijds. 79(4):297-301.
Vissani M.A., Perglione C.O., Zabal O., Alvarez G., Thiry E., Barrandeguy M. \& Parreño V. 2020. Topical ganciclovir reduces viral excretion in mares with equine coital exanthema. J. Equine Vet. Sci. 94:103199. <https://dx.doi. org/10.1016/j.jevs.2020.103199><PMid:33077066>

Vissani M.A., Tordoya M.S., Tsai Y.-L., Lee P.-Y., Shen Y.-H., Lee F.-C., Wang H.-T.T., Parreño V. \& Barrandeguy M. 2018. On-site detection of equid alphaherpesvirus 3 in perineal and genital swabs of mares and stallions. J. Virol. Methods 257:29-32. <https://dx.doi.org/10.1016/j.jviromet.2018.04.002> $<$ PMid:29627335>

Williams K.J., Robinson N.E., Lim A., Brandenberger C., Maes R., Behan A. \& Bolin S.R. 2013. Experimental induction of pulmonary fibrosis in horses with the gammaherpesvirus equine herpesvirus 5. PLoS One 8(10):e77754. <https://dx.doi.org/10.1371/journal.pone.0077754><PMid:24147074>

Yurov K.P. \& Alekseenkova S.V. 2018. Coital exanthema of horses: diagnosis and identification of the pathogen. Rus. Vet. J. 2018(6):5-8. <https://dx.doi. org/10.32416/article_5c050ab891e319.94298054> 